\title{
СТАН ПРООКСИДАНТНО-АНТИОКСИДАНТНОЇ СИСТЕМИ В ТКАНИНАХ ПАРОДОНТА ЗА УМОВ РОЗВИТКУ ЕКСПЕРИМЕНТАЛЬНОЇ БРОНХІАЛЬНОЇ АСТМИ
}

○Б. Ф. Щепанський

\section{Львівський медичний інститут}

РЕЗЮМЕ. Причиною запальних хвороб тканин пародонта можуть бути різноманітні чинники. Будь-які системні захворювання та їх ускладнення, в свою чергу, можуть негативно впливати на патологічні процеси в тканинах пародонта. Гіпоксичні стани, які виникають при бронхіальній астмі (БА), призводять до порушення кисневовідновлювальних процесів і трофіки тканин пародонта.

Мета дослідження - визначення окремих показників перекисного окиснення ліпідів (ПОЛ) та антиоксидантної системи (АОС) у слизовій оболонці пародонта мурчаків при модельному процесі експериментальної БА на 4, 18, 25 доби експерименту.

Матеріал і методи. Досліди були проведені на 40 морських свинках (самцях) масою тіла 0,25-0,27 кг. Тварин поділили на чотири групи, по десять тварин у кожній. Інтактні тварини складали першу групу; тварини з експериментальною БА - другу, третю, четверту групи відповідно на 4, 18, 25 доби експерименту. Експериментальну БА відтворювали за методом В. І. Бабича. В слизовій оболонці пародонта інтактних морських свинок та тварин з експериментальною БА з продуктів ПОЛ визначали вміст малонового діальдегіду (МДА) за методом Е. Н. Коробейнікова, вміст дієнових кон'югатів (ДК) - за методом В. Б. Гаврилова та М. І. Мишкорудної. 3 показників АОС визначали активність супероксиддисмутази (СОД) за методом R. Fried, активність каталази (КT) - за методом B. Нolmes, C. Masters, вміст церулоплазміну (ЦП) - за методом В. Г. Колб та В. С. Камишнікова. Результати дослідження обробляли за методом варіаційної статистики з використанням критерію Стьюдента.

Результати. Результати досліджень показали зміни окремих показників прооксидантно-антиоксидантної системи залежно від періодів формування БА: збільшення вмісту МДА та ДК, збільшення, з подальшим зниженням, активності СОД, КТ, ЦП у всі терміни експерименту.

Висновки. Отримані результати свідчать про значні зміни показників прооксидантно-антиоксидантної системи в слизовій оболонці пародонта експериментальних тварин з БА та $є$ важливими для розуміння патогенезу БА. Дані дослідження дають можливість для пошуку досконаліших та ефективніших методів діагностики БА.

ключовІ СлОВА: бронхіальна астма; перекисне окиснення ліпідів; антиоксидантна система.

Вступ. Останнім часом з'явилися дослідження, у яких вивчали вплив бронхіальної астми (БА) на захворювання пародонта. БА $€$ результатом хронічного запалення дихальних шляхів і на сьогодні спостерігається постійне її поширення у всьому світі. Статистичні дані свідчать, що на даний час приблизно 300 мільйонів осіб страждають від астми та їі наслідків і ще у близько 100 мільйонів буде діагностовано це захворювання до 2025 року [1]. 3 численних даних літератури відомо, що важливу роль у патогенезі розвитку як БА, так і пародонтиту, відіграють зміни прооксидантно-антиоксидантної системи.

Причиною запальних хвороб тканин пародонта можуть бути різноманітні чинники. Будь-які системні захворювання та їх ускладнення, в свою чергу, можуть негативно впливати на патологічні процеси в тканинах пародонта. Гіпоксичні стани, які виникають при тривалому перебігу ХОЗЛ, призводять до порушення киснево-відновлювальних процесів і трофіки тканин пародонта [2].

У доступних нам літературних джерелах не знайдено інформації про стан прооксидантно-антиоксидантної системи при коморбідній патології БА та хронічного пародонтиту.

Метою нашого дослідження було визначення окремих показників перекисного окиснення ліпідів (ПОЛ) та антиоксидантної системи (АОС) у слизовій оболонці пародонта мурчаків при модельному процесі експериментальної БА.

Матеріал і методи дослідження. Дослідження проводили з дотриманням принципів біоетики відповідно до положень Європейської конвенції щодо захисту хребетних тварин, яких використовують в експериментальних цілях (Страсбург, 1986), Директиви Ради Європи 86/609/ЄС (1986), Закону України № 3447-IV «Про захист тварин від жорстокого поводження», загальних етичних принципів експериментів на тваринах, ухвалених Першим національним конгресом України з біоетики (2001).

Комісія з біоетики Львівського національного медичного університету імені Данила Галицького порушень морально-етичних норм при проведенні науково-дослідної роботи не виявила.

Досліди були проведені на 40 морських свинках (самцях) масою тіла 0,25-0,27 кг. Тварин поділили на чотири групи. Перша - інтактні мурчаки (10) - контроль, друга - тварини з БА на четверту добу моделювання захворювання (10), третя - тварини з БА на вісімнадцяту добу моделювання захворювання (10), четверта - тварини з БА на двадцять п'яту добу моделювання захворювання (10). 
Огляди літератури, оригінальні дослідження, погляд на проблему, ювілеї

Модельний процес БА відтворювали за методом В. І. Бабича [3]. Попередньо тварин одноразово сенсибілізували нормальною кінською сироваткою (0,1 мл внутрішньоочеревинно). Потім три дні поспіль вводили підшкірно 0,1 мл нормальної кінської сироватки (НКС) із вбитою в автоклаві БЦЖ (на 1 мг БЦЖ 1,0 мл НКС). Наступні 14 днів щоденно тварини впродовж 30 хв у щільно закритій камері за допомогою розпилювача піддавалися інгаляції НКС по 1,0 мл сироватки на кожну морську свинку. Після закінчення цього терміну кожні 7 днів морським свинкам проводили інгаляції НКС.

Декапітацію інтактних тварин та тварин з БА проводили під ефірним наркозом на четверту, вісімнадцяту, двадцять п'яту доби та забирали зразки слизової оболонки пародонта для визначення показників продуктів ПОЛ та АОС.

3 продуктів ПОЛ визначали вміст малонового діальдегіду (МДА) за методом Е. Н. Коробейнікова [4], вміст дієнових кон'югатів (ДК) - за методом В. Б. Гаврилова та М. І. Мишкорудної [5].

3 показників АOC визначали активність супероксиддисмутази (СОД) за методом R. Fried [6], активність каталази-за методом B. Holmes, C. Mas- ters [7], вміст церулоплазміну (ЦП) - за методом В. Г. Колб та В. С. Камышникова [8].

Статистичну обробку результатів дослідження виконували за методом варіаційної статистики з використанням критерію Стьюдента.

Результати й обговорення. При вивченні деяких показників прооксидантно-антиоксидантної системи в тканинах пародонта мурчаків при експериментальній бронхіальній астмі було встановлено, що в усі досліджувані доби експерименту вказані показники змінювалися, порівняно з контрольною групою тварин. Проведені експериментальні дослідження показали, що при БА у самців зростає вміст продуктів перекисного окиснення ліпідів 3 паралельною активацією і подальшим виснаженням системи антиоксидантного захисту. Так, вміст ДК в слизовій оболонці поступово зростає на 4, 18 та 25 доби моделювання, порівняно з контролем

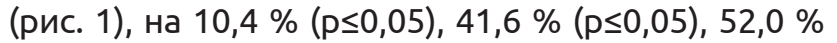
$(p \leq 0,05)$ відповідно. Вміст МДА в слизовій оболонці поступово зростає на 4, 18 та 25 доби моделювання, порівняно з контролем (рис. 1), на 15,0\% $(p \leq 0,05), 21,9 \%$ ( $p \leq 0,05), 27,3 \%$ ( $p \leq 0,05)$ відповідно. Зростання вмісту ДК та МДА вказує на стимуляцію процесів ПОЛ.

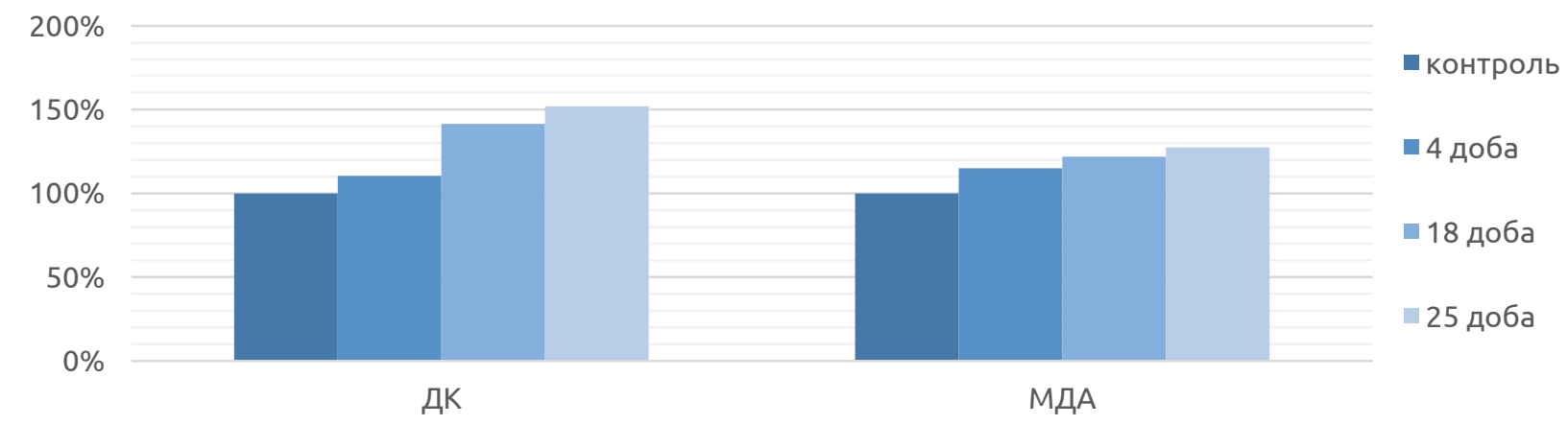

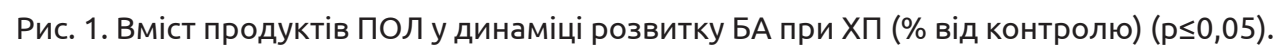

Водночас окремі показники АОС: СОД, КТ, ЦП зростали на 4 добу моделювання, порівняно 3 контролем, на $20,3 \%(p \leq 0,05), 11,4 \%(p \leq 0,05)$ та $52,5 \%$ ( $\leq \leq 0,05)$ відповідно (рис. 2). Зростання цих показників вказує на активацію системи антиоксидантного захисту. На 18 та 25 доби моделювання, порівняно з контролем (див. рис. 2), вміст СОД, КТ, ЦП знижується на $19,0 \%(p \leq 0,05)$ та $27,4 \%(p \leq 0,05)$,

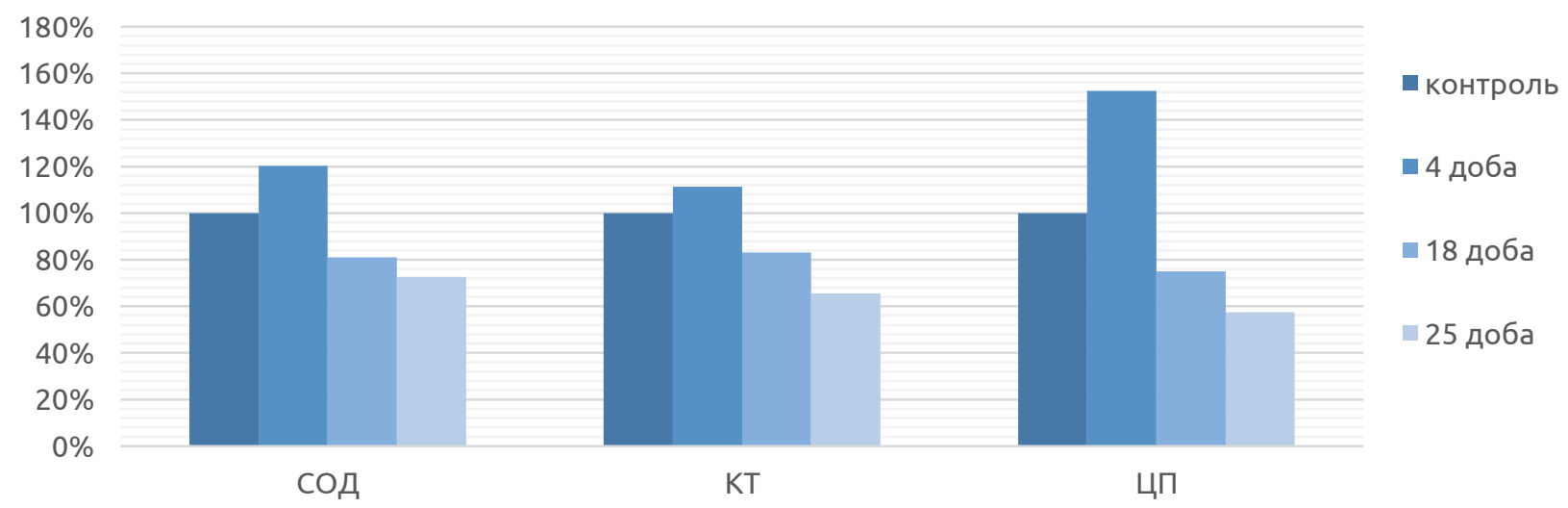

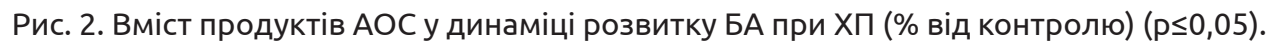


Огляди літератури, оригінальні дослідження, погляд на проблему, ювілеї

на $16,9 \%(p \leq 0,05)$ та $34,4 \%(p \leq 0,05)$, на $25,0 \%$ $(p \leq 0,05)$ та $42,5 \%(p \leq 0,05)$ відповідно, що свідчить про виснаження антиоксидантної системи.

Висновки. Збільшення рівня продуктів ПОЛ та початкове зростання з подальшим зниженням рівня ферментів АОС можуть свідчити про компенсаторну реакцію організму з подальшим ви- снаженням антиоксидантної системи та розвиток оксидативного стресу.

Перспективи подальших досліджень. Вивчення рівня показників ПОЛ та активності ферментів АОС у слизовій оболонці пародонта дає можливість краще зрозуміти вплив БА на порушення киснево-відновлювальних процесів у пародонті.

\title{
ЛІТЕРАТУРА
}

1. Asthma and oral health: A review / M. S. Thomas, A. Parolia, M. Kundabala, M. Vikram // Aust. Dent. J. 2010. - No. 55. - P. 128-133.

2. Патологічні процеси пародонту у хворих на хронічне обструктивне захворювання легень / М. І. Гуменюк, І. П. Мазур, В. І. Ігнатьєва [та ін.] // Астма та алергія. 2013. - № 3. - С. 28-34.

3. Бабич В. И. Модификация метода экспериментальной модели бронхиальной астмы у морских свинок / В. И. Бабич // Проблемы патологии в эксперименте и клинике. - Львов, 1979. - Т. 3. - С. 159.

4. Коробейникова Э. Н. Модификация определения продуктов ПОЛ в реакции с тиобарбитуровой кислотой /Э. Н. Коробейникова // Лаб. дело. -1989. - № 7.C. $8-10$.

\section{REFERENCES}

1. Thomas, M.S., Parolia, A., Kundabala, M., Vikram, M. Asthma and oral health: A review. (2010). Aust. Dent. J., 55 (2), 128-33. doi: 10.1111/j.1834-7819.2010.01226.x.

2. Humeniuk, M.I., Mazur, I.P., Ihnatieva, V.I., Humeniuk, H.L., Lynnyk, N.I., \& Kharchenko-Sevriukova, H.S. (2013). Patolohichni protsesy parodontu u khvorykh na khronichne obstruktyvne zakhvoriuvannia lehen [Pathological process of periodontal patients with chronic obstructive disease of the lungs]. Astma ta alerhiia - Asthma and Allergy, 3, 28-34 [in Ukrainian].

3. Babych, V.I. (1979). Modifikatsiya metoda eksperimentalnoy modeli bronkhialnoy astmy u morskikh svinok [Modification of the experimental model of bronchial asthma in guinea pigs]. (1979). Problemy patolohii v eksperimente i klinike - Problems of Pathology in Experiment and Clinic, 3, 159 [in Russian].

4. Korobeynikova, E.N. (1989). Modifikatsiya opredileniya produktov POL $v$ reaktsii s tiobarbiturovoy kislotoy [Modification of the determination of LPO products in

5. Гаврилов В. Б. Спектрофотометрическое определение содержания гидроперекисей липидов в плазме крови / В. Б. Гаврилов, М. И. Мишкорудная // Лабораторная диагностика ишемической болезни сердца. - К. : Здоровье, 1989. - С. 170-171.

6. Fried R. Enzymatic and non-enzymatic assay of superoxide dismutase / R. Fried // Biochemie. - 1975. - Vol. 57, No. 5. - P. 657-660.

7. Holmes R. Epigenetic interconversions of multiple forms of mouse liver catalase / R. Holmed, C. Masters // FEBS Lett. - 1970. - Vol. 11, No. 1. - P. 45-48.

8. Кол6 В. Б. Определение активности церулоплазмина в крови / В. Г. Колб, В. С. Камышников // Справочник по клинической химии. - Минск : Беларусь, 1982. С. 290-291.

reaction with thiobarbituric acid]. Lab. Delo - Laboratory Case, 7, 8-10 [in Russian].

5. Gavrilov, V.B., \& Mishkorudnaya, M.I. (1989). Spektrofotometricheskoe opredilenie soderzhaniya gidroperikesey lipidov v plazme krovi [Spectrophotometric determination of lipid hydroperoxides in blood plasma]. Laboratornaya diagnostika ishemicheskoy bolezni serdtsa - Laboratory Diagnosis of Coronary Heart Disease. Kyiv: Zdorovye [in Russian].

6. Fried, R. (1975). Enzymatic and non-enzymatic assay of superoxide dismutase. Biochemie, 57 (5), 657-660.

7. Holmes, R. (1970). Epigenetic interconversions of multiple forms of mouse liver catalase. FEBS Lett., 11 (1), 45-48.

8. Kolb, V.B., \& Kamyshnikov, V.S. (1982). Opredeleniye aktivnosti tseruloplazmina $v$ krovi [Determination of the activity of ceruloplasmin in the blood]. Spravochnik po klinicheskoy khimii-Handbook of Clinical Chemistry. Minsk "Belarus" [in Russian].

\section{СОСТОЯНИЕ ПРООКСИДАНТНО-АНТИОКСИДАНТНОЙ СИСТЕМЫ В ТКАНЯХ ПАРОДОНТА В УСЛОВИЯХ РАЗВИТИЯ ЭКСПЕРИМЕНТАЛЬНОЙ БРОНХИАЛЬНОЙ АСТМЫ}

ОБ. Ф. Щепанский

\author{
Львовский медицинский институт
}

РЕзЮМЕ. Причиной воспалительных заболеваний тканей пародонта могут быть различные факторы. Любые системные заболевания и их осложнения, в свою очередь, могут негативно влиять на патологические процессы в тканях пародонта. Гипоксические состояния, возникающие при бронхиальной астме (БА), приводят к нарушению кислородно-восстановительных процессов и трофики тканей пародонта. 
Огляди літератури, оригінальні дослідження, погляд на проблему, ювілеї

Цель исследования - определение отдельных показателей перекисного окисления липидов (ПоЛ) и антиоксидантной системы (АОС) в слизистой оболочке пародонта морских свинок при модельном процессе экспериментальной БА на 4, 18, 25 сутки эксперимента.

Материал и методы. Опыты были проведены на 40 морских свинках (самцах) массой тела 0,25-0,27 кг. Животных поделили на четыре группы, по десять животных в каждой. Интактные животные составили первую группу; животные с экспериментальной БА - вторую, третью, четвертую группы соответственно на 4, 18, 25 сутки эксперимента. Экспериментальную БА воспроизводили по методике В. И. Бабича. В слизистой оболочке пародонта интактных морских свинок и животных с экспериментальной БА из продуктов ПОЛ определяли содержание малонового диальдегида (МДА) по методу Е. Н. Коробейникова, содержание диеновых конъюгатов (ДК) - по методу В. Б. Гаврилова и М. И. Мишкорудной. Из показателей АОС определяли активность супероксиддисмутазы (СОД) по методу R. Fried, активность каталазы (KT) - по методу B. Holmes, C. Masters, содержание церулоплазмина (ЦП) по методу В. Г. Колб и В. С. Камышникова. Результаты исследования обрабатывали методом вариационной статистики с использованием критерия Стьюдента.

Результаты. Результаты исследований показали изменения отдельных показателей прооксидантно-антиоксидантной системы в зависимости от периодов формирования БА: увеличение содержания МДА и ДК, увеличение, с последующим снижением, активности СОД, КТ, ЦП во все исследуемые сутки эксперимента.

Выводы. Полученные результаты свидетельствуют о значительных изменениях показателей прооксидантно-антиоксидантной системы в слизистой оболочке пародонта экспериментальных животных с БА и важны для понимания патогенеза БА. Данные исследования дают возможность для поиска более совершенных и эффективных методов диагностики БА.

КЛЮЧЕВЫЕ СЛОВА: бронхиальная астма; перекисное окисление липидов; антиоксидантная система.

\section{STATUS OF PROOXIDANT-ANTIOXIDANT SYSTEM IN PERIODONTAL TISSUES UNDER CONDITIONS OF THE DEVELOPMENT OF EXPERIMENTAL BRONCHIAL ASTHMA}

\section{@B. F. Shchepanskyi}

\section{Lviv Medical Institute}

SUMMARY. The cause of inflammatory diseases of periodontal tissues can be various factors. Any systemic diseases and their complications, in turn, can negatively influence pathological processes in tissues of a periodontal disease. Hypoxic conditions that arise in bronchial asthma (BA), lead to a violation of the oxygen-reducing processes and trophics of periodontal tissues.

The aim of the study - determination of individual indices of lipid peroxidation (LPO) and antioxidant system (AOS) in periodontal mucosa of guinea pigs during the experimental process of BA on the 4th, 18th and 25th day of the experiment.

Material and Methods. Experiments were conducted on 40 guinea pigs (males), with body weight $0.25-0.27 \mathrm{~kg}$. Animals were divided into four groups of ten animals in each. Intact guinea pigs were the first group. Animals with experimental BA - the second, third, fourth group respectively on the 4th, 18th, 25th day of the experiment. Experimental BA was reproduced by V. I. Babych method. In periodontal mucosa of the intact guinea pigs and animals with experimental BA of LPO products, the content of malondialdehyde (MDA) was determined by method of E. N. Korobeinikov, the content of diene conjugates (DC) was determined by the method of B. B. Havrylov and M. I. Mishkorudna. The activity of superoxide dismutase (SOD) by R. Fried method, catalase activity (CT) by B. Holmes, C. Masters, and the content of ceruloplasmin (CP) by the method of V. H. Kolb and V. S. Kamyshnikov were determined from the AOS parameters. Statistical methods of processing the results of the study were processed by the method of variation statistics using Student's criterion.

Results and Discussion. The results of the research showed changes in the investigated parameters of the prooxidant-antioxidant system depending on the periods of the formation of BA: an increase in the content of MDA and DC, an increase with subsequent decrease in the activity of SOD, CT, CP in all terms of the experiment.

Conclusions. The obtained results indicate significant changes in the parameters of the prooxidant-antioxidant system in the periodontal mucosa of experimental animals with BA and are important for understanding the pathogenesis of BA. These studies provide an opportunity to find the most perfect and effective methods of diagnosis of BA.

KEY WORDS: bronchial asthma; LPO; AOS. 